\title{
Divine mercy spirituality in response to the pandemic
}

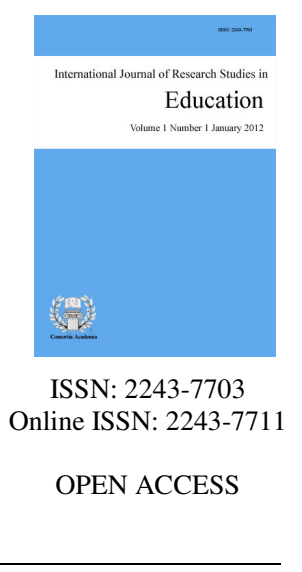

Hirang, Leilani T. $\triangle$

De La Salle University - Manila, Philippines (leilani_t_hirang@dlsu.edu.ph) del Castillo, Fides

De La Salle University - Manila, Philippines (fides.delcastillo@dlsu.edu.ph)

Accepted: 25 October 2020

\begin{abstract}
This paper proposes a kind of spirituality that deals with devotion to Jesus, the Divine Mercy. This spirituality hopes to help people cope during the time of the pandemic. The mixed method in the form of survey and review of related literature were used. Devotion can mean growing in personal holiness and witnessing to others. It can be an attitude of caring about God and of His creations especially those afflicted by the illness. This disease is affecting the local and global communities at large. With the outbreak of the disease, there is a calling for all to respond by trusting in the Divine Mercy and healing of Jesus Christ. There are suggestions to strengthen the body, soul, and spirit of the person. Hence, this research paper hopes to give some positive long term solutions to the growing pandemic cases locally and globally. The data on Covid19 cases showed an increasing number of the afflicted as well as the deaths. Due to these findings, it is highly recommended to deepen the devotion and promote the Divine Mercy and Healing of Jesus especially in the homes, hospitals, offices, online classes and social media during challenging times like the pandemic.
\end{abstract}

Keywords: Covid-19 pandemic; Divine Mercy devotion promotion; education; healing; spirituality 


\section{Divine mercy spirituality in response to the pandemic}

\section{Introduction}

Maurot (2020) once stated that a Catholic French philosopher revealed a crisis of faith and doubt because the Covid-19 patients are increasing. Data on coronavirus showed an increasing number of afflicted also of the death cases. As of October 2020, there are over 43 million cases of this disease, and 1.6 million reported deaths (John Hopkins, 2020). Still, cases are increasing around the world. Medical researchers have begun to discover vaccines that may somehow treat Covid19 patients. Even the Church servants are responding to the signs of the times by helping the government and private institutions in solving this pandemic through social media online masses and other outreach support for the poor and front liners (del Castillo \& del Castillo, 2020). This paper investigates the phenomenology of the Covid19 affecting human and global ecology. The response of the Church to this present crisis is additionally included in the study. The researchers used the See- Judge-Act (SJA) framework (Sands, 2018) to elucidate the phenomena and suggest some possible spiritual solutions to the present pandemic affecting the local and global communities.

\subsection{The global and local situations}

Vergnaud (2020) stated that the COVID-19 is a disease caused by SARS-CoV-2 from Wuhan, China during 2019 and has become a pandemic. Coronaviruses are originally discovered in domestic poultry in 1930. Like, SARS and MERS, the coronavirus could be a zoonotic disease that begins in animals and is transmitted from animals to people. It has become pandemic since late 2019 and up to the present. As a consequence, over 2.2 million new cases and 39,000 deaths of COVID-19 have been reported from America, Southeast Asia, Europe, Eastern Mediterranean, Africa, and Western Pacific. This is the highest number of reported cases by the World Health Organization on its Weekly Epidemiological Update issued on October 5, 2020.

Within the Philippines and abroad, social distancing and an extension of the ECQ or enhanced community quarantine and even total lockdown in some areas with high cases are still implemented including the frequent washing of hands and regularly wearing of masks especially in the public or when going outside, respiratory etiquette, body hygiene, cleanliness of surroundings, establishment closures, stay at home policy, and some restrictions on internal/ external travel/ movement. Reflecting on the death situations and meaning of life, isolation, and confinement are chances to explore these matters and to have an authentic conversion of heart (Hollerich, 2020).

\subsection{Judging in the Light of God's Word and Catholic social teachings}

Biblical spirituality can offer a possible remedy to these problems. For instance, God states in Genesis 1:29 that He has given "each herb bearing seed and each tree within which is the fruit of a tree yielding seed, they shall be for food". It was stated in Ezekiel 47:12 that the fruit can be used as a food and the leaf as a medicine. Whereas, in Psalm 104:14, "He causes the grass to grow for cattle and herb for the consumption of humans". Revelations 22:2 stated that "The leaves of the trees were for the healing of nations".

Based on these biblical verses, there is a possibility that planting more, living a healthier lifestyle, and cleanliness could be the remedies to the covid19 pandemic in terms of ecology. Spirituality, healthy living, and healing reveal intimate links (del Castillo, 2020). It was reported that some people got this virus from the animals they had eaten. Hence, the Scripture offers possible answers regarding food prohibitions and what is allowed to eat. God's word is indeed tried, tested, and true from the beginning of centuries. It can give us hope, inspiration, and possible solutions in these trying times. Reflecting on Pope Francis' Laudato Si, there is an urgent action for a worldwide ecological conversion by caring and respecting God's creations to combat the 
pandemic affecting the local and global societies.

Other Biblical inspirations are taken from Hebrews 4:16 stating to "... draw near to the throne of grace to receive mercy, grace, and help in time of need..." because mercy triumphs over judgment (James 2:13). Whereas, Luke 6:36 quoted: "be merciful because God the Father is merciful." "The works of mercy are charitable acts aiding the poor in their spiritual and bodily basic needs. Instructing, advising, consoling, comforting, forgiving, and bearing wrongs patiently are spiritual works of mercy. In contrast, the corporal works of mercy consist of feeding the hungry, sheltering the homeless, clothing the naked, visiting the sick and imprisoned, and burying the dead. Among all these, giving alms to the poor is one of the chief witnesses to fraternal charity: it is also a work of justice pleasing to God" (CCC 2447) (Catechism of the Catholic Church, 1994).

St. John Paul II (1980) stated that the messianic message about mercy preserves a particular divine-human dimension. Christ - the very fulfillment of the messianic prophecy - by becoming the incarnation of the love that is manifested with particular force about the suffering, the unfortunate, and sinners, makes present and thus more fully reveals the Father, who is God "rich in mercy." At the same time, by becoming for people a model of merciful love for others, Christ proclaims by His actions even more than by His words that call to mercy which is one of the essential elements of the Gospel ethos. In this instance it is not just a case of fulfilling a commandment or an obligation of an ethical nature; it is also a case of satisfying a condition of major importance for God to reveal Himself in His mercy to man: "The merciful...shall obtain mercy." The mercy of God is the mission of the Church. The Church must bear witness to the mercy of God revealed in Christ, in the whole of His mission as Messiah, professing it in the first place as a salvific truth of faith and as necessary for a life in harmony with faith, and then seeking to introduce it and to make it incarnate in the lives both of her faithful and as far as possible in the lives of all people of goodwill. Finally, the Church-professing mercy and remaining always faithful to it-has the right and the duty to call upon the mercy of God, imploring it in the face of all the manifestations of physical and moral evil, before all the threats that cloud the whole horizon of the life of humanity today (Dives in Misericordia, 1980).

\subsection{Action plan}

It was stated in the Gospel of Christ that "by His wounds, we are healed, and by His blood, we are cleansed. Christ also encourages all people to be merciful to one another because of the Merciful Father in heaven. It is observed that many people are doing these mercy ministries in the different sectors. Although the government and medical sectors continue to do their tasks, the local-global Churches are doing their digital outreach tasks spiritually and materially to assist the majority in solving the pandemic issues despite social distancing and residential quarantine. Eucharistic celebrations online are being propagated to ensure spiritual benefits to the people like healing, miracles, protections, and other answered prayers which are derived from attending such online Masses. Added to this, a Marian priest once quoted that the Divine Mercy is the source of all renewal which starts within the family. The central element of the Divine mercy is to awaken and develop the attitude of trust in every believer, which consists of the actualization of the three theological virtues including humility and contrition. Special styles of veneration are merely external ways that should help a believer to develop that habit because without it these external mean lose their spiritual value. The second important element of the veneration is that the works of mercy (Podgorelec \& Bellulo, 2016).

\subsection{Celebrate}

There is a reason to celebrate because the first ray of hope happened last May 2020. Doyle (2020) stated that the pre-clinical research and primary injections materialized in Oxford University's COVID-19 vaccination trial led by Vaccinology Professor Sarah Gilbert of the Jenner Institute marked a serious development to discover a cure for the pandemic, with hopes of manufacturing a vaccine for public use as early as September. Usually, it takes years for the clinical trials, but academics have hastened the process in just weeks. Researchers believe that 
there is an 80 percent chance of the vaccination currently undergoing human trials at Oxford University will work. The four countries like UK, US, China, and Germany contribute to the progress in vaccine search for Covid19.

In the Philippines, the Department of Health (DOH) announced the country's participation in the WHO Solidarity trial which has been approved by the Single Joint Research Ethics Board (SJREB) last April 17. This supported the COVID-19 global response to the World Health Organization's (WHO) launch of a global randomized and adaptive trial "Solidarity" to check the security and effectiveness of 4 possible therapies in treating COVID-19 (WHO, 2020).

Even though the government and medical sectors do their best to find effective vaccines for this disease, the efforts done are not complete without the grace of God. Hence, an authentic way of life or spirituality could be a possible lifelong solution as proposed by the Church officials. Hirang and del Castillo (2020) states that spirituality deals with the way a person lives a spirit-filled life, despite bodily affliction.

\subsection{Objectives of the study}

The research aims to deepen spirituality by promoting the Divine Mercy devotion and healing of Jesus during the Covid19 pandemic. The researchers conducted a survey and review of selected literature regarding the impact of this devotion. Hopefully, this may implicate further spiritual devotion studies and improve the ministerial program of the Church even through digital.

\subsection{Materials and methods}

The study applied mixed research. In this method, the researchers used surveys and review of related literature to discover the experience of the devotees residing in the Philippines. The majority of the respondents are lay servants of the different communities and parishes. They are also devotees of the Divine Mercy.

\section{Literature review}

As an indication of God's liberating and restoring presence in the world, the Church is committed to, and accomplishes, a healing mission: a continuation of Christ's life-giving ministry to the afflicted. Caring for the sick means caring for Christ himself. As stated in Matthew 24:36, Jesus was ill and you took care of him (Hirang $\&$ del Castillo, 2020). In other countries, there are numerous documentations of spiritual congregations taking care of the sick because it was a part of their ministry or service to the poor and the afflicted (Paprocki, 2012). However, during this point of social distancing due to a deadly disease, it is somewhat impossible to travel to search for a priest and ask for his prayer or anointing and even to go to a face to face sacramental confession. Although there are home quarantines within the pastoral ministries for the afflicted of these religious orders who continue to care for the suffering.

The Association of Marian Helpers in the US includes all people, regardless of their age, background, and nationality. They share the devotion to Jesus, the Divine Mercy, and the Blessed Virgin Mary. These Marian Helpers offer prayerful and financial support to sponsor the good works of Marian priests, brothers, and committed lay people around the world (Alar, 2020). According to Fr. Joseph Jarzebowski (2020), the Director of this association in the USA, the Gospel message of Divine Mercy has been handed down over the centuries. The links of this sacred chain extend from the Lord Himself even to the present day. They include a Polish mystic, St. Faustina, who in the 1930s received extraordinary revelations — or messages — from Jesus that she recorded in a 600-page diary. This sacred chain includes the Marian Fathers, who were able to escape Nazi-held Poland with key Divine Mercy materials and spread them through the publishing apostolate in the U.S.A. This sacred chain also includes St. John Paul II, who canonized St. Faustina and entrusted the world to Divine Mercy, calling it the answer to the world's problems. Today, the connection extends to the current pope, to all priests, brothers, and committed lay volunteers. The Divine Mercy message has traveled across continents and war zones.

16 Consortia Academia Publishing (A partner of Network of Professional Researchers and Educators) 
At each step along the way, an individual was personally entrusted with the message by God and asked to spread it. None of these people were perfect. Most of these messengers did not feel prepared or worthy to carry on the Divine Mercy message, yet they did. Some Marian Helpers make it their special mission to spread the Word of devotion. Others spread the message by starting a prayer cenacle or praying the Chaplet of Divine Mercy. Still, others call friends and loved ones at the 3 o'clock hour to share the message of the Divine Mercy. The Divine Mercy message is simply this ... that God is merciful and forgiving and that we, too, must show mercy and forgiveness. It's not a complicated or controversial idea, yet in this pandemic time, this is the wisdom the world needs (Alar, 2020).

In the Philippines, there have been devotions to the Divine Mercy since then. The Apostolic Congress of Mercy was held in Lipa, Batangas last April 2010. That was a decade ago. Since then, there was home propagation of this devotion aside from the parishes. Even to the current situation, Filipinos are getting into online masses and digital devotions. Many are posting on their Facebook pages and messengers for the spread of this devotion of mercy. Some are praying the Divine Mercy Chaplet. The majority are praying the 3 O'clock prayer as shown on the television or using other media. In a charismatic community, for example, the members of the intercessory ministry are devotedly praying it with the pure intention to save the whole world under the guidance and help of the Divine Mercy. All have shortcomings of the glory of God, there is a need for a Merciful savior who can liberate the people from their sins and suffering in this world. Rex (1991) quoted Pope Francis' saying: "A little bit of mercy makes the world less cold and more just" especially in this time of the covid19 pandemic's lockdown and social distancing. There is a need for solidarity instead of seclusion, engagement instead of indifference, faith instead of fear, hope instead of despair, and charity instead of narcissism for the Merciful God loves the afflicted and the poor. What Schwartz means in the sacrament of the poor is the divine indwelling of Christ among the poor as a sign of his presence in the world (Candiasan \& Del Castillo, 2020) that needs healing and comfort. The devotion to the Divine Mercy may bring relief to all poor souls, living or dead.

\section{Experiences of the devotees to the Divine Mercy}

This study will focus on selected devotees of the Divine Mercy and their experiences in doing this devotion during the past and at present. A survey through Google forms was sent in a messenger to the different communities and parishes. A description of the results will then be explained. In the Philippines, there were 23 respondents both male (22\%) and female (78\%), under the ages of 17-62 years old. The majority are lay servants in the different parish and trans-parochial communities. Below were some of their responses:

\section{Table 1}

Participants' responses

\begin{tabular}{|c|c|c|}
\hline Categories & Description & Significant statement examples \\
\hline \multirow[t]{5}{*}{ Favorable experiences } & Physical blessings & $\begin{array}{l}\text { We pray for those who are in dire need of Jesus' Love and } \\
\text { Mercy through physical and spiritual healing. Since we started } \\
\text { praying the Divine Mercy (the beginning of quarantine) our } \\
\text { relationship in the immediate family is better. And now our } \\
\text { relationships outside of the family are healing and getting } \\
\text { better as well. }\end{array}$ \\
\hline & Social blessings & $\begin{array}{l}\text { It helps me to understand and practice mercy. God would } \\
\text { always hear me in times of difficulties and worries; Surviving } \\
\text { during crisis esp. this pandemic. }\end{array}$ \\
\hline & Emotional blessings & $\begin{array}{l}\text { The gratitude of God's Mercy that our family was able to unite } \\
\text { and strengthen our relationships because of this. }\end{array}$ \\
\hline & $\begin{array}{l}\text { Mental/psychological } \\
\text { blessings }\end{array}$ & $\begin{array}{l}\text { Grace and mercy. Conversion, sanctification, and deliverance; } \\
\text { Immense love of Jesus; I have been a devotee of the } 3 \mathrm{O}^{\prime} \\
\text { clock prayer to pray for us and the whole world. So far, I can } \\
\text { feel the divine protection from wicked things and the mercy of } \\
\text { God when I have done wrong or is wronged. My devotion to } \\
\text { the Divine Mercy helps me to be at peace during this } \\
\text { pandemic; }\end{array}$ \\
\hline & Spiritual blessings & Praying the chaplet of the Divine Mercy makes me one with \\
\hline
\end{tabular}


Table 1 ...continued

\begin{tabular}{cll}
\hline Categories & \multicolumn{1}{c}{ Description } & \multicolumn{1}{c}{ Significant statement examples } \\
\hline Challenges encountered & Inner and outer distractions & $\begin{array}{l}\text { May be focusing on Prayer despite the outer \& inner } \\
\text { distractions; } \\
\text { As a new prayer warrior in our community, we lift our special } \\
\text { intentions for healing and even miracles for serious cases by } \\
\text { praying the Divine Mercy Chaplet, especially at 3 pm. }\end{array}$ \\
& $\begin{array}{l}\text { Sometimes I forgot to say it at } 3 \text { pm. } \\
\text { Being firm in faith \& humility; We can't go to church } \\
\text { physically because we only commute to go there and there's } \\
\text { an ongoing pandemic. } \\
\text { To contemplate in the passion of Christ }\end{array}$ \\
&
\end{tabular}

Some devotees find it also difficult to minister to their family members especially those who have liberal or secular ways of living. Some are too preoccupied with technology especially Netflix and mobile legends during their spare time. With the busy schedule of the people in other things, it is challenging to spread this devotion. Also, time and commitment are needed in this devotion. One has to find time to pray to God despite worldly things and attachments. Hence, it is a challenge for others to commit this devotion because it demands so much effort and time from them. This is especially challenging for members with family.

Based on the data gathered, the experiences of the devotees of the Divine Mercy are found to be very favorable and positive despite challenges. It allows them to develop piety and devotion to Jesus and even to the Blessed Mother Mary. It also revives and gives them a deeper sense of faith towards God. It moves them to become more merciful because the devotion itself makes them responsible members of the family, community, Church, and society. Some Filipinos are into this devotion because of the elderly devotees as well as those found in the digital world of devotion. Some of the youth and adults are being evangelized by this social media.

\section{Conclusion and recommendation}

The devotion to the Divine Mercy contributed a lot to the church's ministry and evangelization. They promoted piety among its members from clergy, religious, laity, and even non- parishioners especially during this time of the pandemic. The US Association of the Divine Mercy worked for the Church in helping propagate the Catholic faith even through social media. They also incorporated acts of charity and works of mercy towards the needy. Within the Philippines, many lay servants of the different parishes and communities are into this merciful devotion. The majority has benefited from this both those that are devotees and recipients of their actions.

The paper discovered the experiences of the Divine Mercy devotees within the Philippines. The findings stated that the majority feel very positive about their devotion. Some find it a secure refuge in times of the Covid19 pandemic. Others overcome their difficulties and depressions upon praying the Divine Mercy Chaplet. Some find it an avenue for them to grow in holiness and mercy which is directed to God, to others especially the sick, the dying, the sinners, and therefore the whole world. This made them closer to Mary and Jesus. Some grew in prayers and meditation on the diary of Sister Faustina, while others transformed themselves as responsible persons who follow the ways of Christ. These positive experiences made the devotees satisfied because of the material, the physical, emotional, psychological, and spiritual blessings related to this devotion to the Divine Mercy especially in this time of Covid19 pandemic.

However, there are many distractions within the world including technology and social media. The youth for example may find it boring and not enticing, hence they will settle for movie watching on Netflix or online gaming to alleviate the stress or boredom from home since their socializing is restricted nowadays because of quarantine. This challenge of encouraging devotion of Divine Mercy to teenagers made it difficult for the members to share their ministry except perhaps to the kids and humble ones who are receptive to this devotion because these little ones are easy to convince and evangelize. What is essential is to have a childlike trust in God

18 Consortia Academia Publishing (A partner of Network of Professional Researchers and Educators) 
and others. Reiterating the challenges within the association, a deeper commitment to mercy devotion is crucial. An individual can find time to pray a brief prayer to the Divine Mercy. It only takes 15 minutes or less to pray the Chaplet although those who have enough time at home can pray for every 2 hours to maximize the devotion. Time and energy are essentials to this devotion but a few people find it difficult to devote themselves to prayer because of commitment to their families and other priorities.

Hence, this paper recommends that the devotion to the Divine Mercy will be practiced at home, in social media, and in online distance education (especially in Religious Education). Religious educators can integrate this devotion to their learners during their opening or concluding prayer time within the online class. By encouraging and empowering adolescents and kids, there is a high chance of attracting those who are willing to commit and continue the mission of the Church to become merciful to others. With the ways of the Merciful Jesus, the intercession and inspiration of the Blessed Mother Mary, and also the commitment of the prevailing devotees, the continuation of the ministry of the mercy of the Church makes it possible especially during this time of Covid19 pandemic. It is also suggested to intercede more for a rise of devotees among the kids and the youth within the online education. This can allow the missionary spirit of the Divine Mercy to revive and flourish. This Mercy Spirituality devotion study implicates future research involving the various children and youth who can serve the Church with much passion and zeal for the honor and glory alone of Jesus, our Divine Mercy.

\section{References}

Alar, C. (2019). The call. Retrieved October 1, 2020 from https://www.thedivinemercy.org/articles/call-fr-chris-alar-mic

Alar, C., (2020). Marians of the Immaculate Conception. Retrieved from https://www.thedivinemercy.org/ Candiasan, M., \& del Castillo, F. (2020). Evangelical poverty, core teaching in the life and spirituality of Venerable Aloysius Schwartz, priest and founder. International Journal of Research Studies in Education, 9(4), 11-18. https://doi.org/10.5861/ijrse.2020.5826

Catechism of the Catholic Church. (1994). Vatican City: Libreria Editrice Vaticana.

del Castillo, F. (2020). Health, spirituality, and Covid-19: Themes and insights. Journal of Public Health. https://doi.org/10.1093/pubmed/fdaa185

del Castillo, F., \& del Castillo, C. (2020). Lessons learned from covid-19: advocacy towards the vulnerable. Journal of Public Health. https://doi.org/10.1093/pubmed/fdaa121

Doyle, L. (2020). Coronavirus named: what does COVID-19 stand for. Retrieved October 20, 2020 from https://www.express.co.uk/life-style/health/1241302/Coronavirus-named-COVID-19-meaning-WH

Hirang, L. T., \& del Castillo, F. (2020). Marian spirituality: The experience of legionaries in the Philippines. Asia Pacific Journal of Multidisciplinary Research, 8(2), 41-45.

Hollerich, J., (2020). La civilta cattolica. Retrieved October 1, 2020 from https://laciviltacattolica.com/wp-content/uploads/2020/05/La-Civilta-vol.-4-no.-05.pdf https://doi.org/10.32009/22072446.0520.11

Jarzebowski, J. (2020). The divine mercy. Retrieved October 2, 2020 from https://www.thedivinemercy.org/message/history/marianconnect

John Hopkins University of Medicine. (2020). Coronavirus resource center. Retrieved October 10, 2020 from https://coronavirus.jhu.edu/map.html

John Paul II. (1980). Dives in Misericordia. Retrieved October 1, 2020 from http://www.vatican.va/content/john-paul-ii/en/encyclicals/documents/hf_jp-ii_enc_30111980_dives-inmisericordia.html

Maurot, E. (2020). Catholic philosopher. Retrieved in October 2, 2020 from https://international.lacroix.com/news/catholic-philosopher-says-covid-19-reveals-crisis-of-faith-and-do $\mathrm{ubt} / 12147$

Paprocki, J. (2012). Caring for the sick: The Catholic contribution and its relevance. Notre Dame Journal of Law, 
Hirang, L. T., \& del Castillo, F.

Ethics \& Public Policy, 25(2), 447-461.

Podgorelec, F., \& Bellulo, E. (2016). A theological analysis of the veneration of the divine mercy by St. Faustina Kowalska. Bogoslovska smotra, 86(4), 915-939.

Rex, R. (1991). The Eucharist. In The Theology of John Fisher (pp. 129-147). Cambridge University Press. https://.doi.org/10.1017/CBO9780511520211.009

Sands, J. (2018). Introducing Cardinal Cardijn's See - Judge - Act as an interdisciplinary method to move theory into practice. Religions, 9(4), 129. https://doi.org/10.3390/rel9040129

Vergnaud, S. (2020). Article on Covid19. Retrieved October 19, 2020 from https://www.goodrx.com

World Health Organization. (2020). Who solidarity trial for covid19 patients. Retrieved October 20, 2020 https://www.trialsitenews.com/whos-solidarity-trial-for-covid-19-patients-approved-in-the-philippines-2 0-hospitals-involved/ 